\title{
Grassroots Narratives and Practices of Diversity in Mostar and Novi Sad
}

DOI:

10.1007/978-1-137-43825-6_6

\section{Document Version}

Accepted author manuscript

Link to publication record in Manchester Research Explorer

\section{Citation for published version (APA):}

Goldstein, P. (2015). Grassroots Narratives and Practices of Diversity in Mostar and Novi Sad. In T. Matejskova, \& M. Antonsich (Eds.), Governing through Diversity: Migration Societies in Post-Multiculturalist Times (pp. 104-124). (Global diversities). Palgrave Macmillan Ltd. https://doi.org/10.1007/978-1-137-43825-6_6

\section{Published in:}

Governing through Diversity

\section{Citing this paper}

Please note that where the full-text provided on Manchester Research Explorer is the Author Accepted Manuscript or Proof version this may differ from the final Published version. If citing, it is advised that you check and use the publisher's definitive version.

\section{General rights}

Copyright and moral rights for the publications made accessible in the Research Explorer are retained by the authors and/or other copyright owners and it is a condition of accessing publications that users recognise and abide by the legal requirements associated with these rights.

\section{Takedown policy}

If you believe that this document breaches copyright please refer to the University of Manchester's Takedown Procedures [http://man.ac.uk/04Y6Bo] or contact uml.scholarlycommunications@manchester.ac.uk providing relevant details, so we can investigate your claim.

\section{OPEN ACCESS}


This essay has been published in T. Matejskova \& M. Antonsich (Eds.), Governing through Diversity: Migration Societies in Post-Multiculturalist Times (pp. 104-124).

Cite as:

Goldstein, Piotr. (2015). Grassroots Narratives and Practices of Diversity in Mostar and Novi Sad. In T. Matejskova \& M. Antonsich (Eds.), Governing through Diversity: Migration Societies in Post-Multiculturalist Times (pp. 104-124). London: Palgrave Macmillan.

This is author's original manuscript which has not been edited. The definitive, published, version of record is available here: http://dx.doi.org/10.1007/978-1-137-43825-6 6

\section{Grassroots narratives and practices of diversity in Mostar and Novi Sad}

Piotr Goldstein, The University of Manchester

Yugoslavia, as its name - 'the country of South Slavs' - suggested, was a country whose very existence was based on the ideal of the value of diversity. Different South Slavic peoples and other ethnic groups living among them were to be equal constituents of the country. Despite this narrative, the country collapsed amid the tragic Yugoslav wars of the 1990s which divided its people along ethnic lines. In the aftermath of the wars, the international community has sought to rebuild trust and dialogue across ethnic communities while supporting post-Yugoslav states' transition to democracy. Whereas 'there is no single document that describes the democratic reconstruction model,' be it in the Western Balkans or elsewhere (Ottaway, 2003, p. 314), it is evident from international donor policies that the international community was 'determined to make Bosnia into a multiethnic democratic state'(Ibid., p. 320). The same holds true for other, ethnically diverse areas of the Western Balkans. 
We can presume that two popular academic theories particularly strongly shaped donors' ideas on how reconciliation, peace and democracy could be achieved on the territory of former Yugoslavia. ${ }^{1}$ These, I posit, were on the one hand neo-Tocquevillian theories praising associational life for its capacity to foster trust, co-operation and civic activism, and in particular the work of Putnam whose 'Making Democracy Work' (1992) coincided in publication with the height of the Yugoslav wars. The consequent faith in the power of associational life resulted in huge international investment in 'civil society building' in the region which was followed by 'the mushrooming of NGOs' (Bieber, 2003; Solioz, 2006) emergence of thousands of new Non-Governmental Organisations (NGOs) which competed for donor funding. On the other hand, Intergroup Contact Theory, according to which interpersonal contact can lessen prejudice and stimulate positive attitudes between ethnic groups (Allport, 1954) has put its stamp on the way foreign grants were distributed. Those NGOs which voiced the desire to bring together representatives of different ethnic groups became privileged in obtaining funding and the inter-ethnic mixing within sponsored programmes became a pre-requisite required by many of the donors.

\footnotetext{
${ }^{1}$ Although citing academic sources in policy documents is not a common practice, faith of the international donors in the applicability of the two further described theories becomes evident from the study of such documents. This faith was certainly strengthened by the appreciation of these theories both in academia and the media. For instance, after first publication of 'Making Democracy Work' The Economist announced that: 'if [Putnam's] claims about the essential conditions of successful democracy are correct (and they almost certainly are), then politicians and political scientists alike will have to think again about democracy's prospects in Asia, Latin America and Eastern Europe' (The Economist, cited on the back cover of 'Making Democracy Work'). Similarly, stories of members of the conflicting ethnic groups who became good friends after meeting at a foreign sponsored programme are omnipresent in media reporting and in NGO and donor reports.
} 
This chapter demonstrates how NGOs as well as other civil society actors in two post-Yugoslav cities create and/or make (or make not) use of narratives of diversity, that is: how they position diversity within or outside their agendas and how they couple these narratives with practice. The aim of this chapter is to problematize the assumption that the financial support to civil society in post-war societies, such as those of Bosnia-Herzegovina and Serbia, which goes hand in hand with strict funding guidelines which focus on the promotion of ethnic diversity by means of inter-ethnic encounters, is an effective way of stimulating reconciliation and reestablishing (ethnic) diversity. To this end, it engages on the one hand with Putnam's theory of the value of associational life (1992) and on the other hand with the recent critique of the contact theory and in particular works of Matejskova and Leitner (2011), Valentine (2008), and Bilewicz (2007).

\section{The setting}

The paper is a part of a larger project which explored the condition of civil society in Mostar, the capital of the historical region of Herzegovina, and Novi Sad, Serbia's second biggest city. I chose the two cities because of a combination of similarities and dissimilarities through which, in my belief, they represent phenomena characteristic to many diverse locations on the terrain often referred to as post-Yugoslav. These two cities seem to have much in common: they are both in a way their countries' second cities, they are both river towns, they both had bridges destroyed during the recent Yugoslav wars and both are multi-ethnic. Yet, they are also very different. Mostar is a divided city where Croat and Bosniak populations are separated by an invisible wall that runs along the main Bulevar. It has directly experienced all the atrocities and destruction of the war. Novi Sad has a Serbian majority and many minorities: Hungarians, Slovaks, Croats, Ruthenians, Roma and many others. It was much more fortunate. Apart of having its bridges bombed by NATO forces, it was practically untouched by the fighting. Lowlevel violence towards members of Novi Sad minorities was recorded but in principle the place 
remained peaceful (Bieber \& Winterhagen, 2006). Still, it cannot be said that it was spared the trauma of war. Many of the Novi Sad men were incorporated in the Serbian army and the city experienced an influx of refugees as well as an outflow of those who managed to emigrate, mostly local Hungarians. Because of this, present day challenges in both cities are actually often alike and some parallels can be drawn between the developments in the civil society sphere in both places.

Significantly, from the point of view of study of diversity, the situation in Mostar and Novi Sad is very different from that in cities of Western Europe in which immigrant populations diversify 'host society'. Both Mostar and Novi Sad were ethnically diverse from their very beginnings and in fact are at the moment probably least diverse in their respective histories. The very question of who could be considered the 'host society' is problematic and is often at the heart of local problems. Mostar, until the recent wars had practically equally large and quite evenly spread across the town Bosniak, Croat and Serbian populations which shared the space with minorities such as Jews, Roma and others. The Serbs fled during the war (many of them to Novi Sad) and Croats and Bosniaks remain divided by what used to be the front line. Novi Sad was an Austro-Hungarian town in which local Hungarians shared the space with large DanubeSwabian (German) and Serbian minorities and a multitude of smaller ones (including Greeks, Jews, Armenians and others). Germans were expelled from the city and its region after Second World War while Hungarians became a minority, through several waves of immigrations of Serbs from other areas of former Yugoslavia.

Nowadays, after centuries-long cohabitation and interference of cultures there are few cultural differences between Croats and Bosniaks in Mostar or Serbs and members of most minorities in Novi Sad. Although religion is considered to be an ethnic marker, few of the inhabitants of either of the cities are particularly religious (a phenomenon seen for instance in the fact that in the Bosniak - 'Muslim' - part of Mostar it is much easier to buy alcohol than halal meat). 
Although Bosniak and Croat are claimed to be two separate languages even locals often find them difficult to distinguish. ${ }^{2}$ Similarly, practically all Hungarians in Novi Sad speak perfect Serbian and many do not speak Hungarian. While each of the ethnic groups has its own traditions and celebrations, these are to a large extent known to the others. In this context Western European appraisal of urban diversity (as expressed e.g. in Beauregard \& BodyGendrot, 1999; Binnie, Holloway, Millington, \& Young, 2006) seems little applicable. New hybrid cultures might had emerged here centuries ago, but will not emerge now - simply because the local cultures are to a large extent already hybrid.

Nevertheless, animosities between ethnic groups are still alive and they are nourished by, as Ottaway (2003, p. 317) put it, 'conflict entrepreneurs - leaders determined to keep the conflict alive' to profit from it politically. Their work can be heard in official political discourse but also seen in policies which affect e.g. education or the management of public space. Some of such policies are described further in this chapter. The 'success' of these policies is visible particularly in Mostar where the political scene is divided along, first of all, ethnic lines. All in all, diversity in Mostar and Novi Sad is a challenge, although in a different way than in Western Europe.

\section{Methods}

The research for this chapter was conducted between 2009 and 2014, through participant observation, interviews, two questionnaire surveys and photography used as a research method. Its originality stems from the fact that it has considered not only Western-style NGOs, which

\footnotetext{
${ }^{2}$ For instance, after a screening of a film which was announced to have 'Bosnian/Croatian/Serbian subtitles' at OKC Abrašević, a youth cultural centre in Mostar, I have asked a group of local spectators in which language the subtitles actually where and no one in the group could give me a clear answer.
} 
are often seen as representing civil society and are in the focus of academic research, but also other, so far less researched, civil society actors, such as associations established in times of communist Yugoslavia, informal groups and unregistered movements. In reality, being nongovernmental and organised, all those associations and groups can be regarded NGOs. Because of that in this chapter I use the words NGO, association, organisation and group synonymously.

\section{The four narratives / practices}

The classification that follows is a proposal of framing a range of narratives and practices. In reality these are far from being simple and stable. As NGOs move from one project to another, as their leadership changes and as does the surrounding in which they operate, they may switch from one narrative/practice to another, construct new narratives and achieve practical outcomes they never achieved before. Thus, the proposed classification is far from ultimate and the examples offered should be read as anchored in time: it is likely that by the time you are reading this chapter some of the described associations evolved or changed completely and are now involved in new narratives and new practices.

The classification focuses mostly on ethnic diversity but it also mentions practices which promote other forms of diversity. The idea behind this widening of the focus is that, despite common belief, ethnicity is not always in the centre of conflicts in the Western Balkans. The tension between 'old settlers' (starosedeoci) and 'newcomers' (došljaci) has been often recognised as not less significant than that between different ethnic groups (Jansen, 2005; Rumiz, 2011, pp. 103-104) and for many individuals other tensions may be even more important. Conflicts and discrimination based on gender, age, class, sexual orientation, or physical ability are all vivid in the region. Thus, the classification below appreciates the point raised by Piekut, Rees, Valentine, \& Kupiszewski (2012, p. 2988) who postulate 'shift[ing] the discussion on social diversity from ethnic diversity to broader social diversity.' In particular it 
includes examples of associations which create 'opportunities for residents to have contacts with people different from themselves in terms of age and family status, socioeconomic status, ethnicity, and religion/belief and disability' (Ibid., p. 3006) but also gender and political views. Nonetheless, as will be seen through some of the first examples, such widening of the scope is much less likely to become part of a narrative of NGOs in Mostar, where the ethnic division remains to be the city's most striking problem, than in Novi Sad, a city less traumatically experienced, where the associations themselves often decide to approach many different 'diversities'.

\section{Diversity in abstract}

The first narrative/practice is most typical to some of those NGOs which benefit strongly from foreign funding. Having to fulfil donors' desires of diversity promotion they do get involved in promoting diversity, but focus on promoting diversity as such, rather than facing the challenges of diversity in their own environment. One example could be a programme in Mostar, organised by an NGO whose name and logo, as well as description available in online NGO registers (in English, i.e. addressed at foreign donors), clearly marked it as working towards peace and inter-ethnic dialogue. The ten day event was organised on the very theme of 'diversity'. Indeed, participants came from many different countries - in Western and SouthEastern Europe - and they discussed the challenges of 'building bridges', peaceful cohabitation, tolerance and all other related important concepts. They went to see the newly rebuilt Old Bridge and were so impressed by the (re-)construction that in the aftermath of the programme one of the participants wrote in a student magazine back home that 'the Mostar bridge once again connects people from the two sides of the river.' They also visited a site where a new Mostar synagogue was to be built - not only to serve the remaining three Jews of Mostar, but also to give testimony to the city's multicultural character. General 'tolerance', 'openness' and 
'bridge building' were celebrated. The participants built paper bridges (Figure 1) and discussed problems of colour-based racism in the United Kingdom.

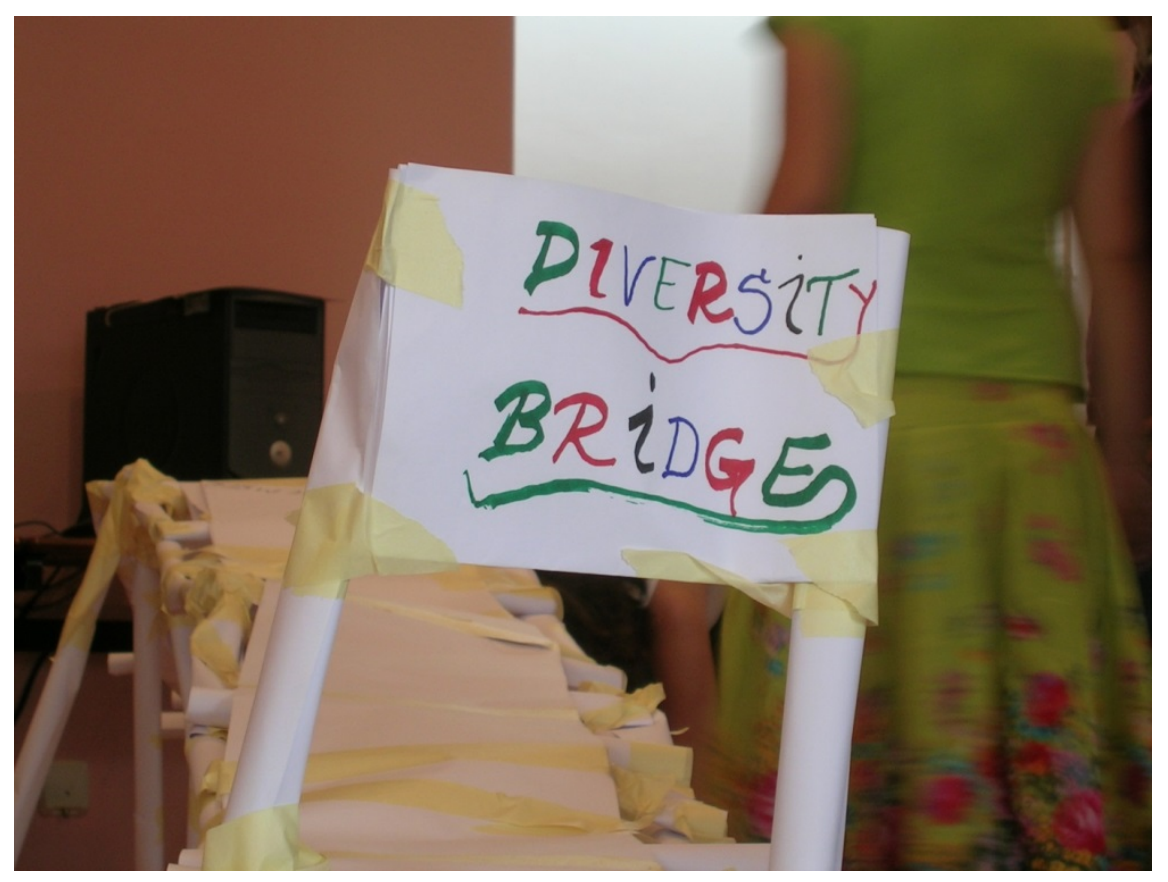

Figure 1: A paper 'diversity bridge' constructed by the participants of a 'diversity programme' in Mostar. Source: Author.

At the same time, during the two weeks of this programme, the other side of Mostar - a city divided between Bosniaks and Croats - was never mentioned, nor demonstrated. It seems that most of the participants have not realised that the newly rebuilt Old Bridge in reality does not connect anyone, as the ethnic barrier runs not on the river but along Bulevar - a street just couple of minutes' walk away from the river. This invisible wall was meters away from participants' everyday routes but they never crossed it. What was cherished and celebrated was the diversity as such, the diversity manifested in embracing the nearly non-existent Jewish community, and the immigrant diversity in Western Europe. The local diversity however, that 
manifested in the city being home to two ethnic groups, remained a taboo - it was neither discussed, nor witnessed.

The roots of such conflicting narrative and practice can be at least twofold. One way to explain the phenomenon is to consider the historical traumas, still vivid in the region. Particularly in settings such as Mostar - a city which experienced all the atrocities of the recent wars (see e.g. the account of Kebo, 2003) - reflections on ethnic diversity can be very painful and its universal value far from obvious. While for a short-time visitor like myself, crossing the invisible wall between Mostar's two parts could be banal, for many of the inhabitants of the city it is both difficult and painful. This problem of ignoring the gravity of the trauma related to the division of Mostar was noticed by Hromadžić (2008, p. 546) who, describing her research experience in Mostar, wrote: 'I crossed the city divide, impatiently, without much thought or fear, as if protesting its existence. Later, however, as I was sinking deeper into the raw life of the city, I felt that the divide became a huge load to carry around, causing frustration and sadness.'

Although Novi Sad did not experience direct fighting between conflicting ethnic groups during the recent wars, also there many of the inhabitants (among them a large number of refugees from other parts of former Yugoslavia) take the ideal of peaceful cohabitation in diversity with scepticism. While in the context of brutal conflict across Yugoslavia, the relationship between the Serbian majority and the minorities of Novi Sad seems to be exemplary, in reality it is complicated. Members of these minorities, particularly Hungarians, often resent the Serbs for the wave of violence they experienced during and in the aftermath of the recent wars (Bieber \& Winterhagen, 2006; Dawson-Szilagyi, 2004). Serbs in turn remember the atrocities committed by Hungarian fascists in Novi Sad during the Second World War and conflicts from more distant past. Many of them see the promotion of diversity coming from the West as a rhetoric similar to that of 'unity and brotherhood' promoted during communist times and, in 
their understanding, proved wrong by the recent wars (Port, 1998, p. 212). In this context it is not hard to imagine that also some of the NGO leaders will share this scepticism.

On the other hand, the fact that some leaders prefer to approach distant and theoretical, rather than local, real-life problems, may have little to do with personal traumas or attitudes towards the question of diversity. To demonstrate the point through an example from another sector: a couple of years ago, one of Novi Sad's environmental groups grumbled on their blog when not a single of Belgrade's many environmental NGOs came to protest against cutting down 300 plane-trees in the centre of the city. They asked '[w]hich environmental NGOs? Those that appeared yesterday to protest against the cutting of plane-trees? Or those that appear only in competitions for grants and organise "seminars" and "lectures" on general topics where they gasp and wonder at the environmental disasters and climate change, but cannot recognise an environmental catastrophe under their window...' (Vojvođanska Zelena Inicijativa, n.d.). It can be argued that there is a group of NGO leaders across Western Balkans who realised that approaching general or distant problems (e.g. 'diversity as such' or climate change) is enough to obtain Western funding. They choose this path as it is far more convenient and safer than approaching local challenges. This way they do not risk being confronted by local opponents of the promoted ideas and also do not need to truly engage local community in their projects. Indeed, a common characteristic of many such NGOs is that they only have three members legal minimum - so in reality they have no membership but only 'leaders'. Their seminars are attended mostly by foreigners, family and friends of the leader and other NGO 'leaders'. This alone makes them unable to fulfil the expectations raised by the research of Putnam: that associations instil in their members mutual trust, foster civic activism and contribute to common meanings which facilitate co-operation across social cleavages (Putnam, 1992; Solioz, 2006). Having no stable membership base such 'associations' are incomparable to those 
researched by Putnam and because of their very nature, their trust- and civic activism-building is likely to be limited.

\section{Local symbolic diversity}

Very different from the above narrative is the second one, in which the celebration-of or, at times, the confrontation-with local diversity takes the central stage. In Mostar, programmes are organised on regular basis whose leaders pride themselves on bringing together, usually young, people from both sides of the city. On these occasions, the phrase 'first-ever encounter of students from both of Mostar's universities' keeps being reused. In Novi Sad, some associations decide to have a multilingual (e.g. Serbian-Hungarian) logo or a plaque in languages of local minorities.

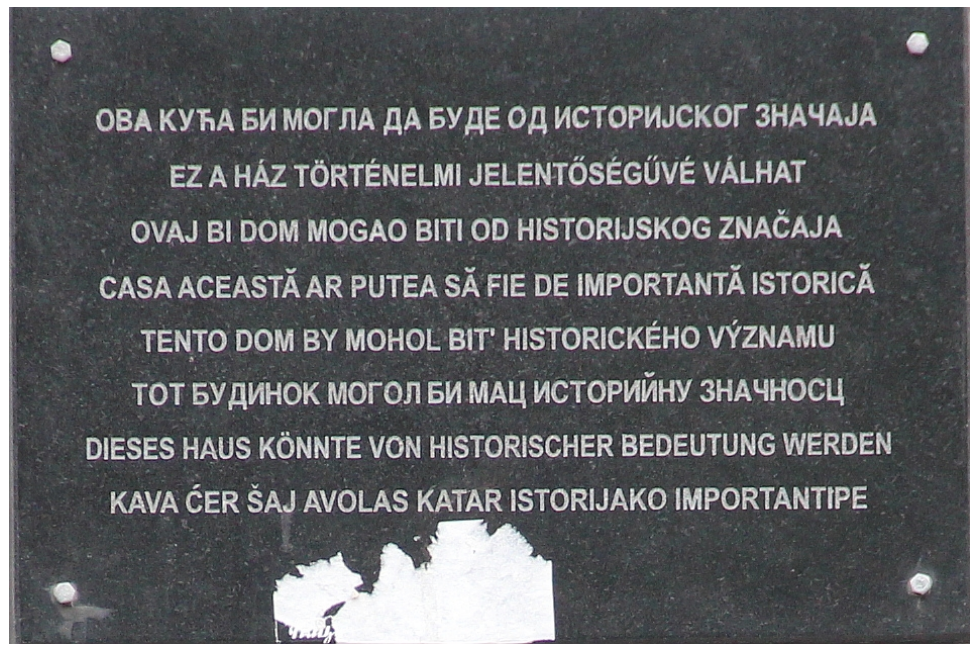

Figure 2. A plaque on the building of a Novi Sad NGO reading: 'This house could be of historical importance' in eight languages. In its multilingual form the plaque relates to the multilingual plaques on public offices of Novi Sad. However the set of languages is somehow different to the official ones. Particularly the inclusion of Romani, language of the Roma, on the list can be seen as significant, as the fact that Romani, despite huge numbers of Roma in the city, is not its official language, is just one of the signs of the 


\section{(political) discrimination of this minority (cf. my study of the political discrimination of} Roma in the EU: Goldstein, 2009). Source: Author.

Although praiseworthy, such initiatives are in most cases much more of a symbol than a reflection of an unprecedented change. In Mostar, 'the first ever meeting' must have taken place many years ago, and in reality young people from the two sides of town do have opportunities to meet and interact, be it during clandestine smoking breaks in the high school bathroom (as described in Hromadžić, 2011), or through other encounters which happen without externally provided inter-ethnic agenda. In Novi Sad a multilingual plaques, logos or websites do not necessarily reflect strong engagement of the minorities in the work of the associations which use them, but are nevertheless used as a statement. For instance, Novi Sad's CK13 has a large multi-lingual plaque by its front gate (Figure 2) and Novi Sad Lesbian Organisation (NLO) has a bilingual Serbian-Hungarian logo. Both organisations are very active and politically engaged and both are involved in numerous projects promoting equality. As $\mathrm{Sara}^{3}$ a leader of NLO who I interviewed asserted, such symbols are made to symbolically oppose the mono-ethnic discourse omnipresent in local politics and celebrate local diversity, but also to act as an invitation for city's minorities to join the NGO. In practice however, although some level of inter-ethnic mixing is always present, for an association to truly engage local minority(ies) in its work, can be a challenge, taking much more than a multilingual plaque or logo to overcome.

At times, such symbolic diversity can become a trump card. As Julia, a foreign volunteer in Mostar, told me, it is impossible not to get funding from foreign sponsors if you organise an

\footnotetext{
${ }^{3}$ All names of individuals in the text have been changed for the sake of anonymity.
} 
encounter of young people from the two sides of town. Because of that, many NGOs in Mostar claim to have organised unprecedented encounters of young Bosniaks and Croats even if the events they organised were very short, involved very few people and/or quite evidently had no impact on the attitudes of young people involved. During one such event I was able witness Yildiz, a foreign volunteer from a distant Asian country, trying to explain Mostar youth that inter-ethnic mixing is good because it works well in her hometown. The young people, most of whom lived all their lives surrounded by nationalist narratives - retold at homes, media and public institutions (Hromadžić, 2008) - seemed little convinced. Rather than enthusiastic towards the presented idea or at least curious of the other, diverse-yet-peaceful Central Asian reality, they smiled discreetly as to express pity at Yildiz who was naïve enough to think that what worked in her country could also work in Mostar.

What is more, quality of implementation aside, it is not obvious whether encounters like this one - which aim to directly confront the ethnic division of the city through debates between young people - really have a potential to change anything for good. Bilewicz (2007) tested the role of contested history on outcomes of inter-group contact between Polish and Jewish students who participated in encounters in Poland, and found out that discussing contested history has distanced young people of the two groups rather than making them more appreciative of each other. Similar point, was made by Matejskova and Leitner (2011) who challenged the contact theory by examining the value of various encounters between Russianspeaking immigrants in Berlin and native German population. Their conclusion was that such encounters, when externally steered, often fail to provide the expected change in attitude. Considering the gravity of the animosity between Croats and Bosniaks in Mostar and that it is based on a recent and still omnipresent conflict, encounters like the one described above are likely to be a challenge for many years to come.

\section{City spaces as memorials of diversity}


A similar narrative/practice is that of NGOs which take on the role of the guardians of (the memory of) diversity. They are determined to oppose those policies, be them pronounced or not, which aim at keeping city's public space and, by extension, public life uniform and/or conflicted. Such policies are orchestrated not only by genuine xenophobes but also by 'conflict entrepreneurs' mentioned earlier.

In Novi Sad, such policies have been implemented already during the communist times. Examples can be seen in destroying the Armenian Church in the centre of Novi Sad and erecting a giant post office which, built diagonally between the octagonal grid of buildings, well obscures the city's synagogue from many view-points. These changes in landscape followed bringing into the city and to the rest of Vojvodina large numbers of ethnic Serbs from other parts of Yugoslavia in the aftermath of the Second World War (Bieber \& Winterhagen, 2006, p. 6). These unpronounced policies, one could argue, aimed at decreasing the role of Vojvodina's ethnic minorities (especially Hungarians) and making the heritage of the ethnic diversity of the region less evident. In Mostar, more recent times have seen an advent of nationalistic strategies in the public space. They are most visible in the way town's churches and mosques were rebuilt after the recent wars. The bell tower of the Franciscan church, situated just by the division line, was rebuilt 'dramatically taller' than it was before the war to become 'the highest bell-tower of the "Croatian people" and in the entire Balkans' (Gunzburger Makaš, 2007, p. 263). At the same time, through 'rediscovery' of long-abandoned and longdestroyed mosques, the number of these temples in Mostar more than doubled between 1980s and their 'rebuilding' in late 1990s (Ibid., p. 294). This happened despite the fact that Mostar's Muslim population is, as mentioned earlier, not particularly religious.

A more discreet manifestation of such policy in Mostar was fencing and complete abandoning of Bogdan Bogdanović's Partisan's Memorial. The Memorial - a cemetery, composed of flower-like tombstones of Second World War partisans of different ethnic groups - is a 
testimony to Mostar's multi-ethnic past. Activists of OKC Abrašević - an important umbrella organisation in Mostar - took on the role of the guardians of the (memory of) diversity and became accustomed to enter through a hole in the fence to show the place to guests and locals alike (Figure 3). The same organisation is engaged in a number of other projects which aim to save from oblivion places which once served as spaces of encounter for Mostar's multi-ethnic population. It is clearly an ambition of these activists to remind the citizens of Mostar that, despite today's omnipresent nationalist propaganda, living-in-diversity in their city is possible.

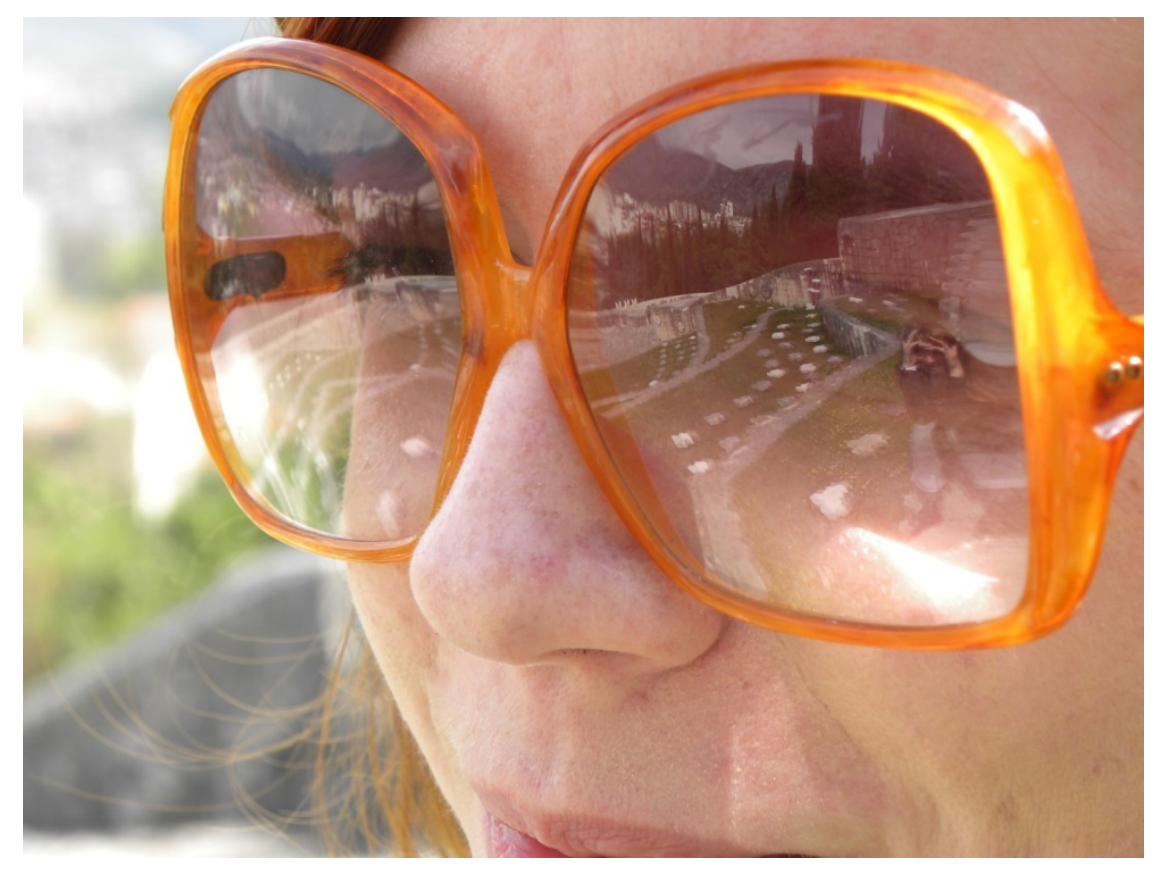

Figure 3. An NGO activist looking at the Bogdan Bogdanović's Partisan's Memorial. Source: Author.

It can be argued that the 'memory' which these people guard is actually shaped by naïve nostalgia. It is very likely that the records of bygone exemplary coexistence between Mostar's ethnic groups find their source, at least partially, in the propaganda of 'brotherhood and unity' omnipresent in the times of Tito, communist Yugoslavia's authoritarian leader. Such at least was an impression of Bojan, a sociologist who visited Mostar in 1980s. According to him 
already then 'everyone knew where Croats go out, where Bosniaks go out and where Serbs go out' (informal communication, August 2013, in Novi Sad). Nonetheless, such nostalgia should not be looked upon as useless. According to a study of Palmberger (2008), it can be very powerful in providing 'vision for a better future' - motivate Mostar's youth to question the omnipresent mono-ethnic discourse and actively engage in the interethnic dialogue and cooperation.

Less nostalgic, was the initiative of Novi Sad's 'Women Studies and Research' which focused on another type of diversity. The association published a map of Novi Sad which shows places related to famous women of the city (many of them members of today's minorities). The idea behind the initiative was to interrupt male-domination of the city's public space, visible for instance in the fact that most of the monuments in the city present men and that only four streets in the entire town are named after women. The map contributes to guarding the (memory of) gender diversity in Novi Sad's public areas and, one could think, has a potential to impact on these women and men of Novi Sad who will come across the map.

Similarly to actions of those groups which use the narrative of symbolic diversity, initiatives like the ones described above are praiseworthy and, at least symbolically, important. It is however very difficult to estimate their impact. Most probably, this impact is limited: not many people will make it to a tour of hard to find spaces testifying to Mostar's multi-ethnic past and few will reach out for a map of 'Novi Sad from a female perspective'. The majority of those who will, are likely to be people engaged in work of NGOs, and others who already have moderate worldviews and appreciate all types of diversity.

\section{Beyond the discourse of diversity: Interest-based encounters}

Finally, some associations manage to have truly (ethnically) diverse membership without formally putting diversity on their agendas. There are at least two paths leading to such situation. 
One is when association's leadership consciously decides not to play on the 'diversity discourse' and to ignore the omnipresent 'ethno-politics'. That is, to distance themselves both from the mono-ethnic agenda omnipresent in local politics and from the multi-ethnic agenda of the international donors. The idea such leaders try to promote is that the entire ethnicity-discourse does not bring anything good to the region. Similar point was made by Florian Bieber who, back in 2002, has identified 'over-institutionalizing ethnicity' as one of the key problems of foreign assistance to Bosnia-Herzegovina. He noted that: '[t]he international organizations have, while opposing extremist parties, continued to emphasize ethnicity in both the institutions and informal arrangements. Reminiscent of the communist rule, when the "ethnic key" was of paramount importance, ethnicity permeates all institutions and spheres of governance. The emphasis on ethnicity tends to render the emergence of more integrative concepts difficult to take hold' (Bieber, 2002). It is probably leaders and some members of such associations that in my questionnaire did not answer the question 'how would you define your ethnicity/national belonging [nacionalnost]?' or wrote in the provided space 'I would not', 'cosmopolitan', 'terrestrial' or 'I don't like this question.' Such leaders appreciate diversity and usually hope to attract diverse audiences, nonetheless they restrain from pronouncing this desire. A good example could be the co-operation between local NGOs, informal initiatives and foreign volunteers which led to organising a festival of 'fire juggling and moving arts' in Novi Sad in 2011. Diversity, 'bridge-building', peace and other such concepts were never said to be the theme nor feature of the encounter. Its themes were: juggling, fire and moving arts. Nonetheless, the event has brought together a large number of participants from across Western Balkans, members of local minorities, and guests from neighbouring Eastern European countries. Within the festival, which lasted four days, high-school students from Serbia and Croatia joined-in for 
many-hours long trainings of parkour ${ }^{4}$ and spent days together. Many of the Novi Sad students hosted their Croatian peers at homes. It was evident that in some cases close friendships were established.

Another case of associations which put diversity outside of their agendas are those associations whose leadership seems really not to care about ethnic, or any other diversity. One of Mostar's mountaineering clubs - an association established in the times of communist Yugoslavia could serve as an example. Similarly as with the fire-juggling and moving-arts initiative, the common interest, in this case - appreciation of the mountains - is in the centre of its agenda, rather than an urge to 'build bridges', 'promote diversity' or bring anyone together. Yet, the association's mountain hikes are a unique phenomenon in Mostar and it can be argued that they contribute to building numerous 'bridges' and promote diversity. These hikes not only bring together Bosniaks and Croats, but also young and old, locals and foreigners, those with higher education and those without, rich and poor. The contrast between the cheap flip-flops (sic!) and old t-shirts of some participants, and the high-end mountain gear of others, attracts the attention of people like myself but does not seem to be a serious problem for those regularly participating in the hikes. The hikes take place regularly and one hike can easily attract a busor two buses-full of participants.

The reason for both the attitude to diversity of the mountaineering club's leadership and its success in bringing together many diverse people may lay in the fact that the association is not sponsored from the West. Because of that, it is clear for members that the hikes that the club organises are indeed aimed at them, the participants, and are not put on in order to please a foreign sponsor or allow leaders to boast about (and later profit from) the impact of their

\footnotetext{
${ }^{4}$ Parkour is a physical discipline which focuses on fast and efficient movement around obstacles on a way from one point to another. It is usually practiced in urban spaces.
} 
association. The club, not being funded from the West, does not have an 'ethnic agenda' and therefore allows people to get together and enjoy the mountains without having to declare their ethnicity to fulfil a necessary quota. Participants come because they want to and not because of someone's need to demonstrate that the association is effective in 'stimulating a post-war reconciliation.' Similarly, when I was cycling in Kritična Masa (Critical Mass) in Novi Sad, among hundreds of other cyclists who join together on the last Friday of the month to ride through the streets of the city, I could hear many participants speaking Hungarian. They were there not because of an invitation aimed directly at them as members of an ethnic minority but because of all the other things that the event had to offer. As in similar studies (e.g. Matejskova \& Leitner, 2011), encounters organised around a theme of interest to all the participants appeared more successful in bringing members of different ethnic groups together, than those themed on diversity, inter-ethnic understanding, etc.

Another aspect of such associations is that they do have, often numerous, membership made of members of local communities. Thus they have a potential to fulfil expectations raised by the research of Putnam (1992) - to become 'networks of trust' and to make their members generally more trustful (also towards members of other ethnic communities) and civically engaged. However, whether in this post-war context this actually happens is not clear. Valentine in her study of the significance of encounter (2008) gives an example of a white Englishman who has good neighbourly relations and chats regularly with his immigrant neighbour and still remains racist (p. 329) and concludes that the 'proximity does not equate with meaningful contact' (p. 334). Matejskova \& Leitner in turn observed that although attitudes towards particular individuals may change through regular encounters, these are unlikely to be 'scaled-up' to the entire immigrant community. Likewise, a questionnaire that I conducted among members of one Novi Sad NGO to test its capacity to generate trust, showed that although close friendships were established in this NGO's structures (across ethnic, gender, 
generational and other lines), these had little effect on becoming more trustful towards people outside the organisation. These examples put in doubt both the value of encounter and the particular role of associations as a space of encounters across diversity. Further research, on a larger number of associations is needed to determine whether in the post-war Western Balkan context civil society actors fulfil this role.

\section{Conclusions}

This chapter considered the ways in which civil society actors in two post-Yugoslav locations, approach diversity: the narratives they do, or do not, create and the ways in which they approach diversity in practice. The first point that this chapter made is that the researched postYugoslav civil society actors operate in, to a large extent, 'post-diverse' environment: one which used to be much more diverse and cosmopolitan than it is now and in which local cultures are already hybrid rather than different. Thus, diversity is a challenge for local communities but differently than in Western Europe or in the US. Local conflicts are grounded not in actual difference but in historical traumas and are cultivated by those who profit from their existence. This specificity of the context is one of the reasons for which policies of Western donors, particularly these influenced by the intergroup contact theory, result in creation of NGO narratives which are followed by conflicted or ineffective practices.

This research outlined four narratives/practices created/practiced by civil society groups in Mostar and Novi Sad. It showed that these groups are strongly influenced by, on the one hand, local realities in which ethno-centric politics often take the central role, and on the other hand, by expectations of foreign donors who aim at counter balancing these politics and push for multi-ethnic activities and encounters. NGO leaders' personal needs, ambitions and traumas, whereas often difficult to clearly recognise, without doubt shape the practices of their organisations and can be another reason for which specific narratives/practices are created. 
Two of the assessed narratives correspond, in the most part, with practice and are praiseworthy. Some NGOs, against omnipresent nationalistic (but also misogynistic, homophobic, etc.) policies, take on the role of guardians of (the memory of) diversity and aim at saving from oblivion positive examples of diversity benefiting their communities in the past. Others, through the use of symbols, show to the world that diversity is important to them: they use multilingual logos or plaques or organise events during which their city's ethnic conflict is discussed. These narratives/practices represent a creative approach to local challenges. However, it can be suspected that among groups who create the letter narrative/practice are also these which include diversity in their agendas to please foreign donors. This seems to be the case particularly with groups (repeatedly) organising 'first ever' encounters of Bosniak and Croat youth in Mostar, which are known to easily attract attention of Western donors. Another concern is that the actual impact of the two narratives and corresponding practices may in fact be limited: events and publications praising diversity usually attract people who do not need to be convinced of its value, and symbols are rarely enough to truly engage minorities in work of particular associations or to effectively promote change in attitudes. These observations are in line with earlier findings of Belloni (2001) who noted that ' $[\mathrm{t}]$ he end result [of donor support to civil society in Bosnia-Herzegovina] is, on the one hand, a transnational cosmopolitan community of like-minded people who speak the same "language" (literally and symbolically) and share an ethos that is degrees removed from territorially based identities. On the other hand, the majority is excluded (often due to lack of language skills, education, and opportunity) and clings to exclusionary and intolerant ethnically based identities' (p. 177). Nevertheless, both Belloni's and my own conclusions are based on observations of immediate or relatively shortterm impact, or actually, lack of it. In reality, the symbols and small-scale encounters may bring effects with time and it is perhaps too early to judge them useless. 
The other two of the identified narratives appeared paradoxical. On the one hand, this of the observed NGOs which probably used the word 'diversity' most and in its programming continuously referred to promotion of diversity, 'building bridges', etc. in reality restrained from confronting challenges of ethnic conflict in its own city. On the other hand, some groups and initiatives never mentioned such concepts but they evidently brought together people of different ethnic groups (but also young and old, men and women, reach and poor) regularly and with ease. The roots of this paradox can be traced to foreign funding and its policies. Donors are happy to sponsor these associations which get involved in their own, albeit oversimplified and at times neo-colonialist, narrative, e.g. that ethnicity is in the centre of all Western Balkans' problems and that examples of best-practice from other parts of the world are likely to provide necessary tools to local leaders and stimulate change. At the same time members of local communities are tired of such narratives, as they resemble them communist propaganda of 'brotherhood and unity' and ignore the gravity of their own traumas. Nonetheless, members of local communities are often happy to engage in multi-ethnic, and in other ways truly diverse, activities when such narratives are absent and when the activities meet their needs and interests, such as mountain hiking, cycling or juggling with fire.

This research, was at first meant to be a comparison of dynamics in two, very different, case study locations. However, it soon appeared that despite striking differences between the cities, the developments in civil society sphere in both places follow similar patterns. In particular, any of the discussed narratives could be observed in any of the two cities, and the relationship between donor policies and narratives of associations was evident in both places. Two aspects in which results from the two locations could be compared were the frequency of particular narratives and the approach to promoting different diversities. Paradoxical narratives which aim at pleasing foreign donors but are not going in pair with practice which would appreciate local diversity are particularly visible in Mostar. This is an outcome of the fact that the city is 
divided so it attracts considerable attention of donors who, particularly here, insist on diversity being in the core of NGO programming and are pleased whenever the two ethnic groups are brought together, whilst the local conflict is still grave and not everyone is ready to get engaged in overcoming it. At the same time, dealing with diversities different than the ethnic one is uncommon in Mostar. On contrary, in Novi Sad, a city where ethnic animosities are considered to be just one of many local challenges, NGOs approach all types of social diversities. Here, with the ethnic question not being in the core of donor strategies to an extent to which it is Mostar, also conflicted narratives are less common.

Theories praising associational life and intergroup contact have had strong impact on the shape of donor support to post-war Western Balkans. They were, it seems, adopted uncritically, resulting in broad support to NGOs coupled with donor policies favouring multi-ethnic encounters and work on the theme of diversity. This chapter showed that such policies result in, often conflicting, NGO narratives and practices, but also that some grassroots practices come to being without, or perhaps despite, donor intervention. Such practices, rooted in needs, hobbies and interests which spread across ethnic lines, seem to be more effective than any of those which come hand in hand with pro-diversity narratives. Still, the capacity of associations to effectively promote diversity by providing space for inter-ethnic and otherwise diverse encounters, should not be taken for granted. Findings of this research support the recent critique of contact theory in that the encounters organised by NGOs may not necessarily be significant. More long term research in this particular context is needed to assess this capacity.

\section{References}

Allport, G. W. (1954). The Nature of Prejudice. Cambridge, MA: Addison-Wesley. 
Beauregard, R., \& Body-Gendrot, S. (1999). The Urban Moment: Cosmopolitan essays on the late-20th-century city. Thousand Oaks, CA: Sage.

Belloni, R. (2001). Civil Society and Peacebuilding in Bosnia and Herzegovina. Journal of Peace Research, 38(2), 163-180.

Bieber, F. (2002). Aid Dependency in Bosnian Politics and Civil Society: Failures and Successes of Post-War Peacebuilding in Bosnia-Herzegovina. Croatian International Relations Review, 8(26/27), 25-29.

Bieber, F. (2003). The Other Civil Society in Serbia: Non-governmental nationalism - the case of the Serbian resistance movement. In P. Kopecký \& C. Mudde (Eds.), Uncivil Society? Contentious politics in post-communist Europe (pp. 18-34). London and New York: Routledge.

Bieber, F., \& Winterhagen, J. (2006). Ethnic Violence in Vojvodina: Glitch or Harbinger of Conflicts to Come? Flensburg. Retrieved April 02, 2013, from http://www.ecmi.de/uploads/media/working_paper_27.pdf

Bilewicz, M. (2007). History as an Obstacle: Impact of Temporal-Based Social Categorizations on Polish-Jewish Intergroup Contact. Group Processes \& Intergroup Relations, 10(4), 551-563.

Binnie, J., Holloway, J., Millington, S., \& Young, C. (2006). Cosmopolitan urbanism. London and New York: Routledge.

Dawson-Szilagyi, B. (2004). The Conflict in the Former Yugoslavia and Autonomous Region of Vojvodina, and the Need for a More Coherent U.S. Foreign Policy. Washington, DC: The American Hungarian Association. Retrieved from http://www.americanhungarianfederation.org/docs/The Conflict in Vojvodina.pdf

Goldstein, P. (2009). Political Discrimination of the Rroma in the European Union. Unpublished MA thesis, International University Institute for European Studies, Gorizia. Retrieved from https://www.escholar.manchester.ac.uk/uk-ac-man-scw:121091

Gunzburger Makaš, E. (2007). Representing Competing Identities: Building and rebuilding in postwar Mostar, Bosnia-Herzegovina. Unpublished PhD thesis, Cornell University. Retrieved from http://www.academia.edu/2211279/4_Building_Rebuilding_Remembering

Hromadžić, A. (2008). Discourses of integration and practices of reunification at the Mostar Gymnasium, Bosnia and Herzegovina. Comparative Education Review, 52(4), 541-63.

Hromadžić, A. (2011). Bathroom Mixing: Youth Negotiate Democratization in Postconflict Bosnia and Herzegovina. PoLAR: Political and Legal Anthropology Review, 34(2), 268289.

Jansen, S. (2005). Who's Afraid of White Socks? Towards a Critical Understanding of PostYugoslav Urban Self-Perceptions. Ethnologia Balkanica, (9), 151-167. 
Kebo, O. (2003). The Mostar Story, or the Twenty-first-century Berlin. In G. Glasson Deschaumes \& R. Iveković (Eds.), (pp. 106-11). New Delhi; New York: Oxford University Press.

Matejskova, T., \& Leitner, H. (2011). Urban encounters with difference: the contact hypothesis and immigrant integration projects in eastern Berlin. Social \& Cultural Geography, 12(7), 717-741.

Ottaway, M. (2003). Promoting democracy after conflict: the difficult choices. International Studies Perspectives, (4), 314-322.

Palmberger, M. (2008). Nostalgia Matters: Nostalgia for Yugoslavia as potential vision for a better future. Sociologija, 50(4), 355-70.

Piekut, A., Rees, P., Valentine, G., \& Kupiszewski, M. (2012). Multidimensional diversity in two European cities: thinking beyond ethnicity. Environment and Planning A, 44(12), 2988-3009.

Port, M. van de. (1998). Gypsies, Wars and Other Instances of the Wild: Civilisation and Its Discontents in a Serbian Town. Amsterdam: Amsterdam University Press.

Putnam, R. D. (1992). Making Democracy Work: Civic Traditions in Modern Italy. Princeton: Princeton University Press.

Rumiz, P. (2011). Maschere per un massacro. Quello che non abbiamo voluto sapere della guerra in Jugoslavia. Milano: Feltrinelli Editore.

Solioz, C. (2006). Strengths and Weaknesses of Civil Society in the Balkans: Continuities from Conflict to Peace. Istanbul. Retrieved from http://www.ceiseu.org/events/2006/doc/2006_istanbul.pdf

Valentine, G. (2008). Living with difference: reflections on geographies of encounter. Progress in Human Geography, 32(3), 323-37.

Vojvođanska Zelena Inicijativa. (n.d.). Sve može... samo trba znati. Retrieved January 15, 2012, from http://www.vojvodjanskazelenainicijativa.org.rs/reakcije.html 